\title{
Synthesis of five and six-membered heterocycles bearing an arylpiperazinylalkyl side chain as orally active antinociceptive agents
}

\author{
Claudia Vergelli ${ }^{\mathrm{a}}$, Giovanna Ciciani ${ }^{\mathrm{a}}$, Agostino Cilibrizzi ${ }^{\mathrm{b}}$, Letizia Crocetti ${ }^{\mathrm{a}}$, Lorenzo Di Cesare Mannelli ${ }^{\mathrm{c}}$, \\ Carla Ghelardini ${ }^{c}$, Gabriella Guerrini ${ }^{\mathrm{a}}$, Antonella Iacovone ${ }^{\mathrm{a}}$, Maria Paola Giovannoni ${ }^{\mathrm{a}, *}$ \\ a NEUROFARBA, Sezione di Farmaceutica e Nutraceutica, Università degli Studi di Firenze, Via Ugo Schiff 6, 50019 Sesto Fiorentino, Firenze, Italy \\ ${ }^{\mathrm{b}}$ Department of Chemistry, Imperial College London, South Kensington, London SW7 2AZ, UK \\ ' NEUROFARBA, Sezione di Farmacologia e Tossicologia, Università degli Studi di Firenze, Viale Pieraccini 6, 50139 Firenze, Italy
}

\section{A R T I C L E I N F O}

\section{Article history:}

Received 3 June 2015

Revised 31 August 2015

Accepted 31 August 2015

Available online 2 September 2015

Keywords:

Synthesis

Antinociception

Adrenergic system

\begin{abstract}
A B S T R A C T
A number of heterocycles bearing an arylpiperazinylalkyl side chain and structurally related to the previously described lead ET1 (4-amino-6-methyl-2-[3-(4-p-tolylpiperazin-1-yl)propyl]-5-vinylpyridazin-3 $(2 \mathrm{H})$-one) was synthesized and tested for their antinociceptive activity in Writhing Test. Many compounds, tested at doses of $20-40 \mathrm{mg} / \mathrm{kg}$ po were able to reduce the number of abdominal constrictions by more than $47 \%$ and, in same cases, the potency is comparable to lead ET1 as for 5e, 24a, 27b and 27c. The analgesia induced by the active compounds was completely prevented by pretreatment with $\alpha_{2}$-antagonist yohimbine, confirming the involvement of the adrenergic system in the mechanism of action for these new compounds.
\end{abstract}

(c) 2015 Elsevier Ltd. All rights reserved.

\section{Introduction}

Pain relief continues to be an important medical and community problem and millions of people worldwide use drugs for different pain intensity. The identification of new analgesic agents with limited side effects, as for acute and chronic pain, represents an important research field for pharmaceutical industry and academic. In fact the two major classes of analgesic drugs, the traditional non-steroidal anti-inflammatory drugs (NSAIDs) and opioids, showed severe side effects.

NSAIDs, primarily used for the treatment of mild to moderate inflammatory pain ${ }^{1}$ induce gastrointestinal lesions, such as ulcerations and perforations, nephrotoxicity and inhibition of platelet aggregation. ${ }^{2}$ Development of potent and selective COX-2 inhibitors ${ }^{3}$ only partially solved the problem, since recent studies correlated the use of these inhibitors with an elevated risk of acute myocardial infarction. ${ }^{4,5}$ On the other hand, the clinical use of opioid, for moderate to severe pain, is associated with very strong and use-limiting side effects, including respiratory depression, constipation, tolerance and physical dependence. ${ }^{6}$

A particular search field regards compounds active on neuropatic pain, which is often resistant to conventional analgesic

\footnotetext{
* Corresponding author. Tel.: +39 0554573682.

E-mail address: mariapaola.giovannoni@unifi.it (M.P. Giovannoni).
}

drugs. ${ }^{7}$ Recently defined by the International Association for the Study of Pain (IASP) as 'pain caused by a lesion or disease of the somatosensory system,, 8 neuropathic pain is a complex phenomenon characterized by burning pain coupled with hyperalgesia and allodynia involving both the peripheral and central nervous system. ${ }^{9}$ At present, first-line drugs recommended for this pathology include anticonvulsant, as gabapentin and pregabalin, ${ }^{10,11}$ antidepressants, as amitriptyline and nortriptyline ${ }^{12,13}$ and serotonin-norepinephrine reuptake inhibitor antidepressant as duloxetine $^{14,15}$ and milnacipran ${ }^{16}$ as well as compounds belonging to different therapeutic classes. ${ }^{17,18}$

Our studies in the field of analgesic agents let us to identify a large number of potent compounds, with pyridazine scaffold ${ }^{19-28}$ and the most interesting term is ET1 (Fig. 1), belonging to the series of arylpyperazinylalkyl pyridazinones. ${ }^{28}$ It results a potent and orally active antinociceptive agent showing an $\mathrm{ED}_{50}=0.5 \mathrm{mg} / \mathrm{kg}$ in the hot plate test and a comparable activity in the tail flick test $\left(E D_{50}=0.8 \mathrm{mg} / \mathrm{kg}\right)$. The adrenergic system is involved in the analgesic activity of ET1 as demonstrated by its ability to act as $\alpha_{2}$ AR agonist. ${ }^{28}$ Recent studies show its activity in a model of peripheral neuropathy (data not shown).

We report here the synthesis and the antinociceptive evaluation of a series of pyridazinones derivatives as elaboration of the lead ET1. At the same time, we designed and synthesized new compounds bearing an arylpiperazinyl moiety linked to different heterocyclic system through alkyl chains. 


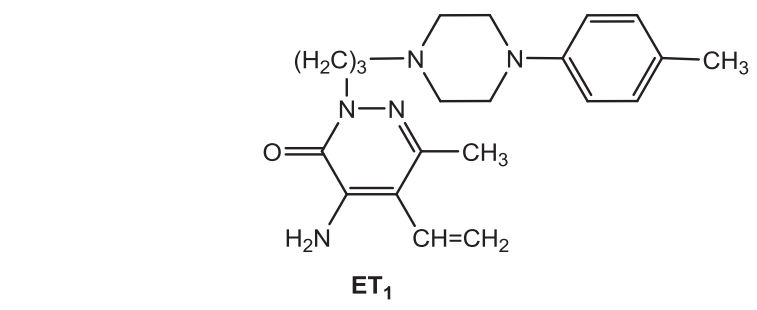

4-Amino-6-methyl-2-[3-(4- $p$-tolylpiperazin-1-yl)propyl]-5-vinylpyridazin-3(2H)-one

Figure 1.

\section{Chemistry}

All new compounds were synthesized as reported in Schemes 1-4 and the structures were confirmed on the basis of the analytical and spectral data.

Scheme 1 shows the synthetic pathway affording the final compounds $5 \mathbf{a}-\mathbf{g}\left(\mathbf{5 d}^{28}\right.$, alias ET1) and $\mathbf{6}$, in which we reported modifications at position 5 or 6 of lead ET1. The 4-amino-5-acyl derivatives $\mathbf{2 a - g}\left(\mathbf{2 d}-\mathbf{g}^{29,30}\right)$ were obtained starting from isoxazolo[3,4-d]pyridazinones $\mathbf{1} \mathbf{a}-\mathbf{g}^{30-32}$ by reductive cleavage with ammonium formate and $\mathrm{Pd} / \mathrm{C}$ and represent the key intermediates of the reported synthetic pathway. The alkylation of $\mathbf{2 a - g}$ with 1-(3-bromopropyl)-4-( -tolyl)-piperazine ${ }^{28}$ under standard conditions afforded compounds $3 \mathbf{a}-\mathbf{g}\left(\mathbf{3 d}^{28}\right)$ which were reduced with sodium borohydride in methanol to give the corresponding secondary alcohols $\left(\mathbf{4 a}-\mathbf{g}, \mathbf{4} \mathbf{d}^{28}\right)$, which finally were transformed into the final 4-amino-5-vinyl derivatives $5 \mathbf{a}-\mathbf{g}\left(\mathbf{5 d}^{28}\right)$ with polyphoshoric acid (PPA) (5a-e, 5g) or with sulfuric acid adsorbed on silica gel (5f). The vinyl group of $\mathbf{5 d}$ was further reduced with Parr instrument to afford compound $\mathbf{6}$.

In Schemes 2 and 3 are depicted the synthesis of ET1 analogues bearing a different $\mathrm{N}-2$ basic side chain with respect to lead compound.

In Scheme 2 compounds 8a-c were obtained from 4-amino5-acetylpyridazinone $\mathbf{2 d}{ }^{29}$ following two different procedures: a direct alkylation of 2d with 1-(3-bromopropyl)-4-(4-fluorophenyl)piperazine ${ }^{24}$ in anhydrous DMF and $\mathrm{K}_{2} \mathrm{CO}_{3}$ at room temperature, for $\mathbf{8 a}$, or through the synthesis of $\mathrm{N}$-butylbromide 7 followed by condensation with the appropriate R-arylpiperazine for $\mathbf{8 b}, \mathbf{c}$. Final compounds $\mathbf{1 0 a}-\mathbf{c}$ were then obtained following the same synthetic procedure described in Scheme 1.

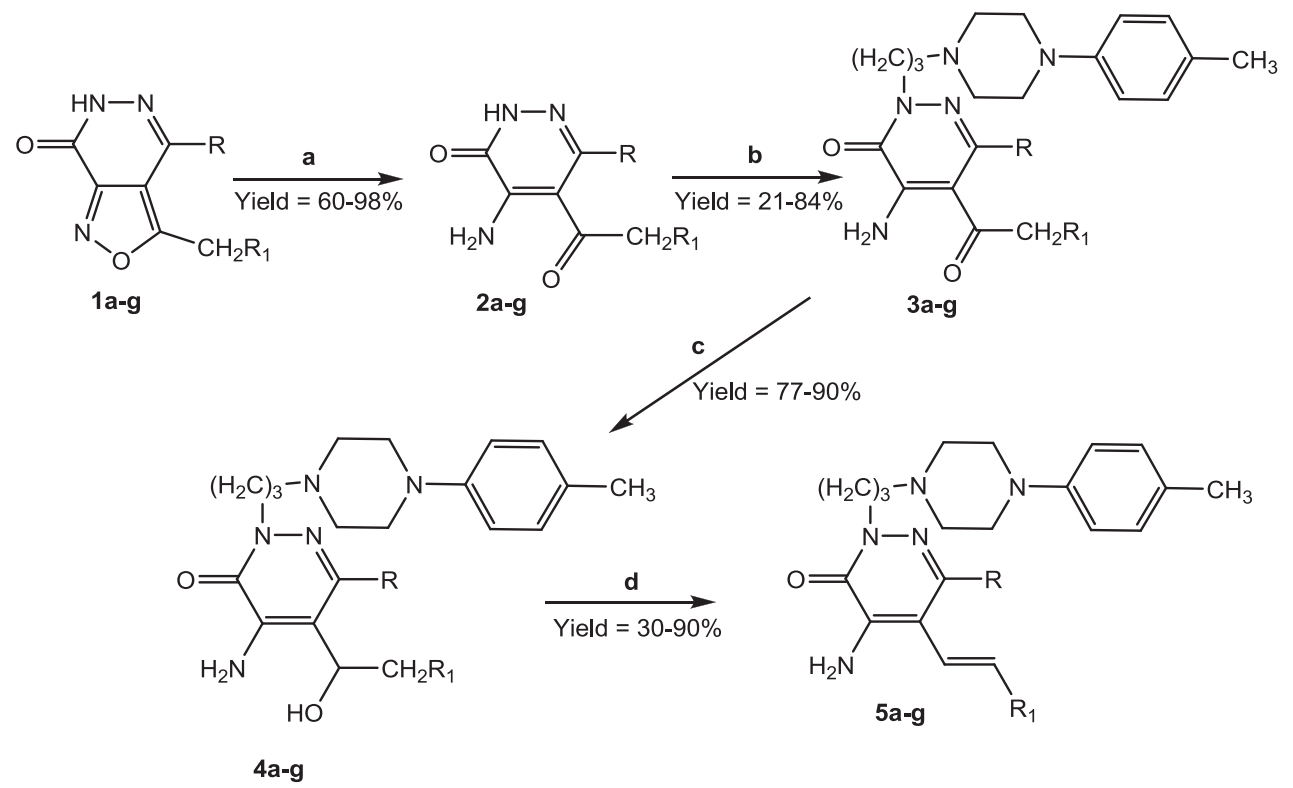

\begin{tabular}{|c|c|c|}
\hline $\mathbf{1 - 5}$ & $\mathbf{R}$ & $\mathbf{R}_{\mathbf{1}}$ \\
\hline $\mathbf{a}$ & $\mathrm{C}_{2} \mathrm{H}_{5}$ & $\mathrm{H}$ \\
$\mathbf{b}$ & $\mathrm{nC}_{3} \mathrm{H}_{7}$ & $\mathrm{H}$ \\
$\mathbf{c}$ & $\mathrm{nC}_{4} \mathrm{H}_{9}$ & $\mathrm{H}$ \\
$\mathbf{d}$ & $\mathrm{CH}_{3}$ & $\mathrm{H}$ \\
$\mathbf{e}$ & $\mathrm{CH}_{3}$ & $\mathrm{CH}_{3}$ \\
$\mathbf{f}$ & $\mathrm{CH}_{3}$ & $\mathrm{C}_{2} \mathrm{H}_{5}$ \\
$\mathbf{g}$ & $\mathrm{CH}_{3}$ & $\mathrm{nC}_{3} \mathrm{H}_{7}$ \\
\hline
\end{tabular}

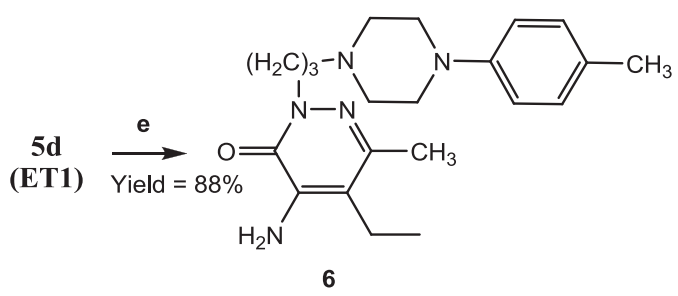

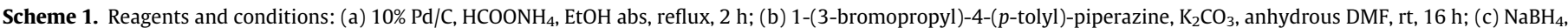

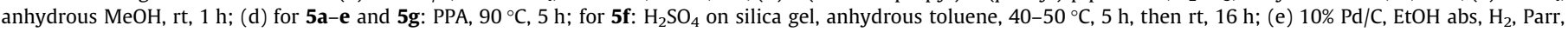
60 PSI, 5 h. 


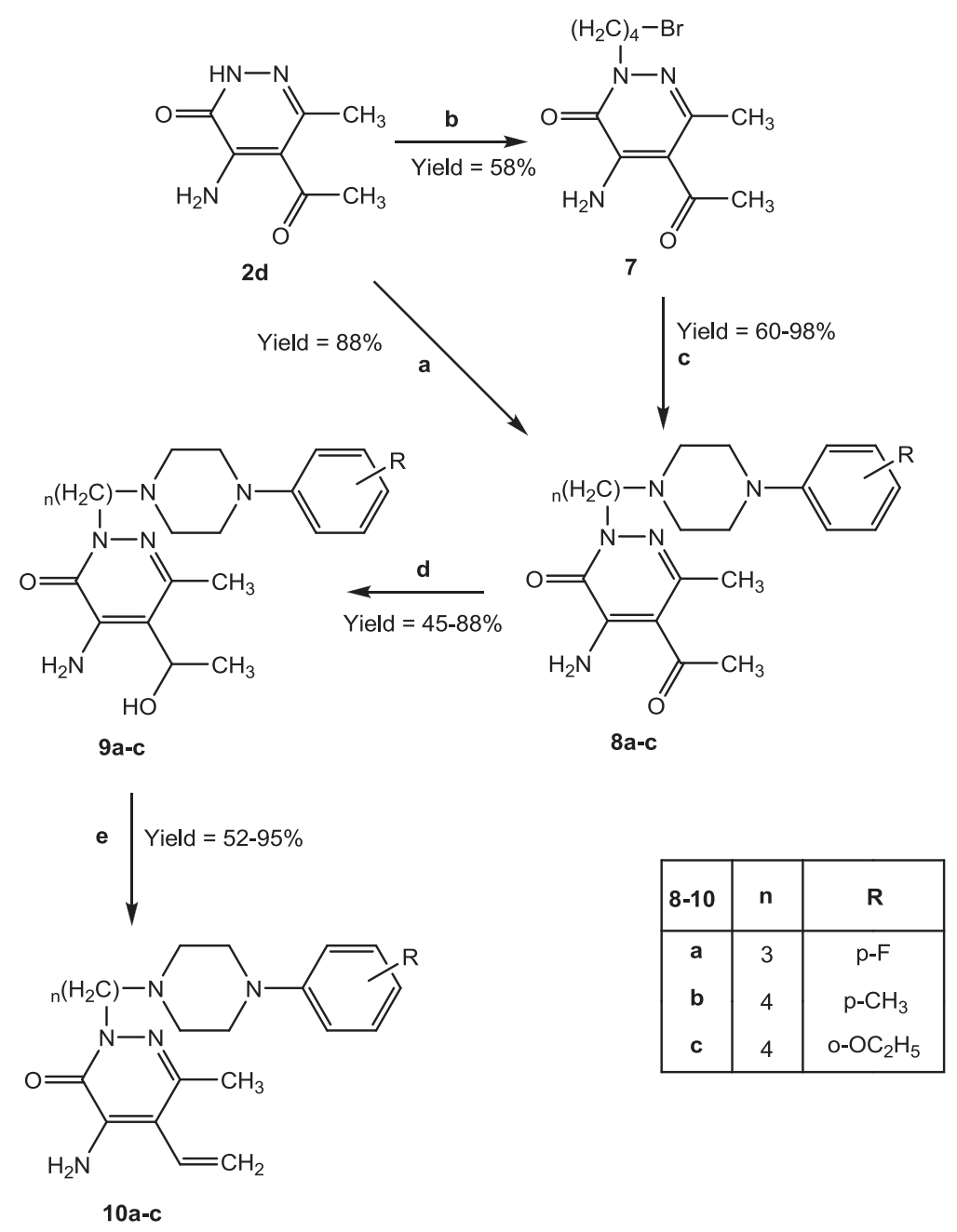

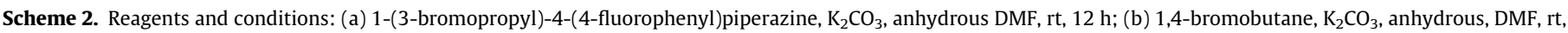
$3 \mathrm{~h}$; (c) appropriate R-arylpiperazine, $\mathrm{K}_{2} \mathrm{CO}_{3}$, anhydrous DMF, rt, $18 \mathrm{~h}$; (d) $\mathrm{NaBH}_{4}$, anhydrous $\mathrm{MeOH}, \mathrm{rt}, 5-20 \mathrm{~min}$; (e) PPA, $70{ }^{\circ} \mathrm{C}, 3 \mathrm{~h}$.

Further modifications of the side chain are reported in Scheme 3. The basic fragment 13, 16 and 18 were prepared by condensing 1,3-dibromopropane or 1-bromo-3-chloro-2-methylpropane with appropriate substituted-arylpiperazine 12, 15 and 17 in anhydrous acetone and $\mathrm{K}_{2} \mathrm{CO}_{3}$ at room temperature (part 1). Compounds 11, 12, 14 and 15 are commercially available, while compound $\mathbf{1 7}$ was synthesized following the procedure reported in leterature. ${ }^{33}$ Fragment 13, 16 and 18 were then used for the synthesis of the final compounds 21a-c in the same conditions described in Scheme 1 (part 2).

Finally, in Scheme 4 is represented the synthetic pathway affording the final compounds 24a-e, 27a-e and 30a-c, characterized by a different heterocyclic scaffolds. The starting compounds $\mathbf{2 2}^{34}, \mathbf{2 5}$, commercially available, and $\mathbf{2 8}^{35}$ undergo to the usual synthetic route to give the desired compounds of type 24, 27 and 30.

\section{Biological results and discussion}

The antinociceptive activity of the new products was evaluated per os in the experimental model of the abdominal constriction test $^{36}$ and data are reported in Tables $1-3$ in comparison with that of lead, compound ET1.

Starting from the modification at position 6 of ET1 (Table 1, compounds $\mathbf{5 a}-\mathbf{c}$ ) the replacement of $\mathrm{CH}_{3}$ with $\mathrm{C}_{2} \mathrm{H}_{5}(\mathbf{5 a})$ or $\mathrm{C}_{3} \mathrm{H}_{7}$ (5b) was associated with complete a loss of activity, whereas the presence of a butyl group (5c) unexpectedly determined an interesting antinociceptive effect with an appreciable reduction of constriction at 20 and $40 \mathrm{mg} / \mathrm{kg}$.

The effects of the elongation of the vinyl group at position 5 was also studied: substitution of a hydrogen at $\beta$-carbon with a methyl group (compound $\mathbf{5 e}$ ) afforded a potent antinociceptive agent able to reduce for $44 \%$ and $63 \%$ the abdominal constrictions at 20 and $40 \mathrm{mg} / \mathrm{kg}$, respectively therefore with an activity comparable to lead ET1. Further lengthening (compounds $\mathbf{5 f}$ and $\mathbf{5 g}$ ) clearly suggested that position 5 shows specific requirements of steric hindrance as demonstrated by the progressive decrease of potency of compounds $\mathbf{5 f}$ and $\mathbf{5 g}$.

Finally, the 5-acyl 3a, 3d-g and 5-ethyl derivatives $\mathbf{6}$ were synthesized as metabolically more stable homologues of lead ET1. In any case, these modifications led to compounds less potent then ET1 and in the series of 4-acyl derivatives, it is possible to observe a trend similar to vinyl derivatives since antinociceptive activity decreases moving from $\mathbf{3 d}\left(5-\mathrm{COCH}_{3}\right)$ to $\mathbf{3 g}\left(5-\mathrm{COC}_{4} \mathrm{H}_{9}\right)$.

In Table 2 was reported the antinociceptive activity of ET1 derivatives modified at the arylpiperazinylalkyl chain at position 2. All compounds were less active (10a and 21c) or completely inactive (10c and 21b) than the reference compound. Only derivatives 10b and 21a, at $30 \mathrm{mg} / \mathrm{kg}$ per os showed an appreciable antinociceptive activity reducing by $42 \%$ and $47 \%$, respectively, the number of abdominal constrictions. These data indicated that the best arrangement for the basic side chain is represented by 


\section{Part 1}<smiles>Cc1ccc(N2CCN(CC(C)CCl)CC2)cc1</smiles><smiles>O=C(c1ccc(Cl)c(F)c1)N1CCN(CCCBr)CC1</smiles>

15

16<smiles>Cc1ccc(N2CCCN(CCCBr)CC2)cc1</smiles>

\section{Part 2}<smiles>CC(=O)c1c(C)n[nH]c(=O)c1N</smiles>

2d

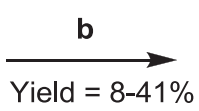<smiles></smiles>

$19 a-c$

c Yield $=68-77 \%$<smiles>C=Cc1c(C)nn([13CH3])c(=O)c1N</smiles>

21a-c

\begin{tabular}{|c|c|}
\hline 19-21 & basic side chain \\
\hline a & b \\
\hline c
\end{tabular}

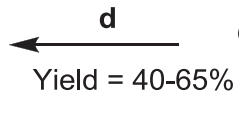<smiles>Cc1nn([13CH3])c(=O)c(N)c1C(C)O</smiles>

20a-c

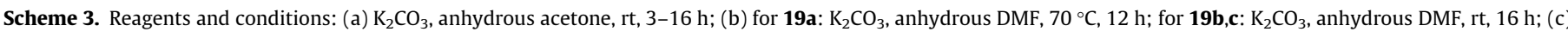
$\mathrm{NaBH}_{4}$, anhydrous $\mathrm{MeOH}$, rt, $10 \mathrm{~min}-1 \mathrm{~h}$; (d) PPA, 70-90 ${ }^{\circ} \mathrm{C}, 3-5 \mathrm{~h}$.

the sequence $p$-tolyl-pyperazinyl-alkyl where the alkyl linker $-\left(\mathrm{CH}_{2}\right)_{3}-($ ET1 $)$ is the best, but can be homologated to $-\left(\mathrm{CH}_{2}\right)_{4}-$ (10b) or branched (21). All other modifications such as substitution of the $\mathrm{p}-\mathrm{CH}_{3}$ group with a fluorine (10a) or the enlargement of piperazine to homopiperazine (21c) was detrimental for activity.
Finally, in order to evaluate the role of the pyridazinone scaffold, we synthesized a new series of compounds in which appropriate propylpiperazinylaryl chains were inserted in different heterocycles (Table 3 ). In the subseries of pirazoles (24a-e), the most interesting compounds resulted derivatives 24a and 24e 


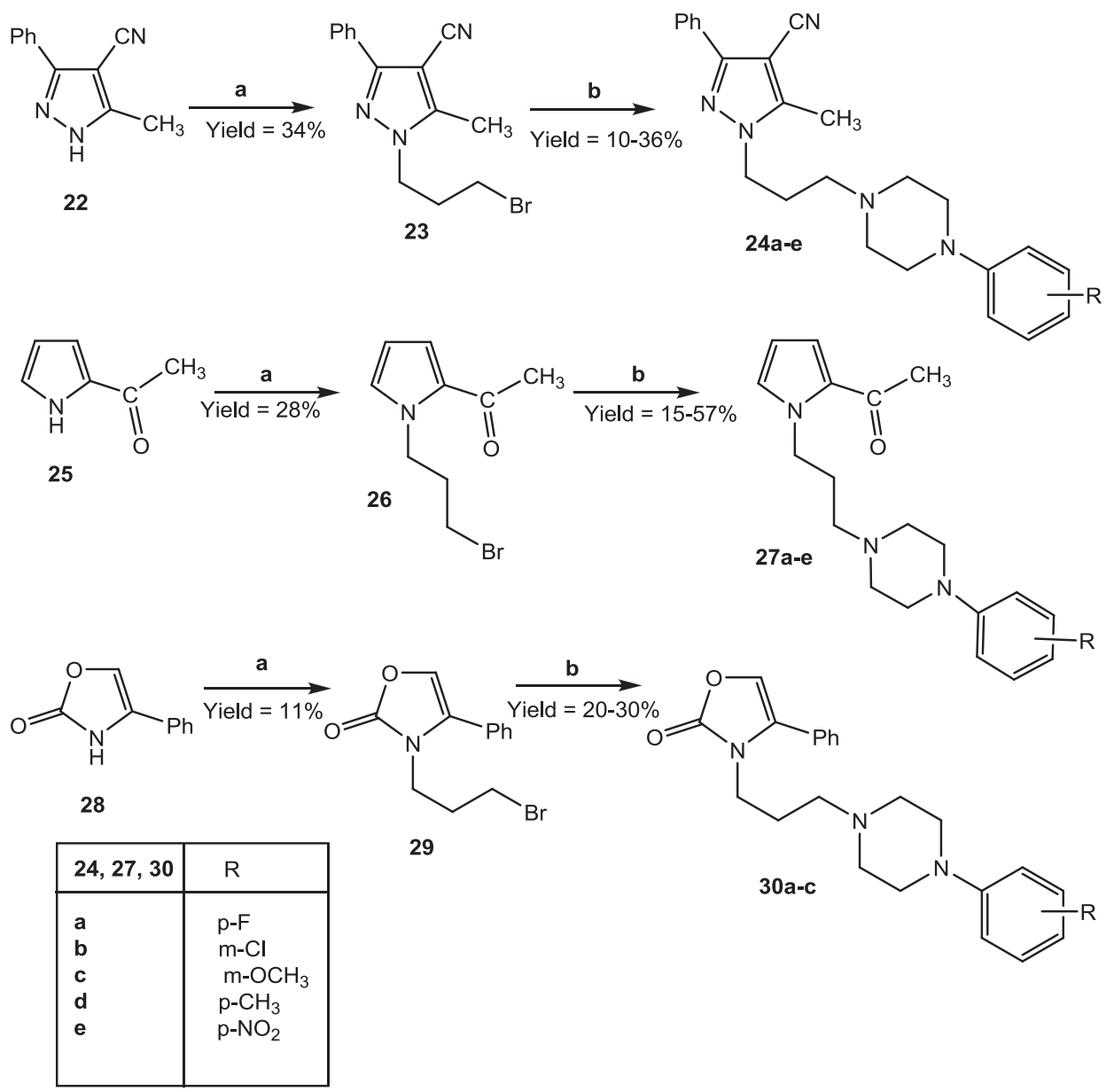

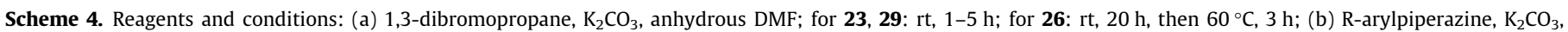
anhydrous DMF, rt-60 ${ }^{\circ} \mathrm{C}, 20-24 \mathrm{~h}$.

Table 1

Antinociceptive effect of final compounds in the Writhing Test ${ }^{\mathrm{a}}$<smiles>[R6]c1nn([AlH2])c(=O)c(N)c1[R6]</smiles>

3a, 3d-g, 5a-c, 5e-g, 6

\begin{tabular}{|c|c|c|c|c|c|c|}
\hline Compound & $\mathrm{R}_{5}$ & $\mathrm{R}_{6}$ & $\mathrm{~N}^{\circ}$ mice & Treatment $\left(\mathrm{mg} \mathrm{kg}^{-1}\right)$ & Abdominal constrictions & $\%$ rid $n^{\circ}$ constrictions \\
\hline CMC & & & 23 & & $30.2 \pm 1.3$ & \\
\hline $5 a$ & $\mathrm{CH}=\mathrm{CH}_{2}$ & $\mathrm{C}_{2} \mathrm{H}_{5}$ & $\begin{array}{l}7 \\
9 \\
5 \\
10\end{array}$ & $\begin{array}{l}10 \\
20 \\
40 \\
40+\text { yohimbine }\end{array}$ & $\begin{array}{l}33.4 \pm 2.1 \\
32.1 \pm 3.1 \\
21.6 \pm 3.0^{*} \\
34.0 \pm 2.6\end{array}$ & $\begin{array}{l}0 \\
0 \\
28\end{array}$ \\
\hline $5 b$ & $\mathrm{CH}=\mathrm{CH}_{2}$ & $\mathrm{C}_{3} \mathrm{H}_{7}$ & $\begin{array}{l}6 \\
7 \\
6 \\
7\end{array}$ & $\begin{array}{l}10 \\
20 \\
40 \\
40+\text { yohimbine }\end{array}$ & $\begin{array}{l}29.4 \pm 3.5 \\
28.2 \pm 3.7 \\
23.6 \pm 3.1^{\wedge} \\
31.9 \pm 3.4\end{array}$ & $\begin{array}{l}3 \\
7 \\
22\end{array}$ \\
\hline $5 c$ & $\mathrm{CH}=\mathrm{CH}_{2}$ & $\mathrm{C}_{4} \mathrm{H}_{9}$ & $\begin{array}{l}6 \\
6 \\
7 \\
8\end{array}$ & $\begin{array}{l}10 \\
20 \\
40 \\
20+\text { yohimbine }\end{array}$ & $\begin{array}{l}33.1 \pm 2.2 \\
17.9 \pm 2.6^{*} \\
15.6 \pm 2.7^{*} \\
29.8 \pm 3.5\end{array}$ & $\begin{array}{l}0 \\
41 \\
48\end{array}$ \\
\hline
\end{tabular}


Table 1 (continued)

\begin{tabular}{|c|c|c|c|c|c|c|}
\hline Compound & $\mathrm{R}_{5}$ & $\mathrm{R}_{6}$ & $\mathrm{~N}^{\circ}$ mice & Treatment $\left(\mathrm{mg} \mathrm{kg}^{-1}\right)$ & Abdominal constrictions & $\%$ rid $n^{\circ}$ constrictions \\
\hline $5 e$ & $\mathrm{CH}=\mathrm{CH}-\mathrm{CH}_{3}$ & $\mathrm{CH}_{3}$ & $\begin{array}{l}5 \\
6 \\
8 \\
8\end{array}$ & $\begin{array}{l}10 \\
20 \\
40 \\
20+\text { yohimbine }\end{array}$ & $\begin{array}{l}33.1 \pm 3.3 \\
16.8 \pm 2.8^{*} \\
11.3 \pm 2.5^{*} \\
27.4 \pm 3.0\end{array}$ & $\begin{array}{l}0 \\
44 \\
63\end{array}$ \\
\hline $5 f$ & $\mathrm{CH}=\mathrm{CH}-\mathrm{C}_{2} \mathrm{H}_{5}$ & $\mathrm{CH}_{3}$ & $\begin{array}{l}5 \\
6 \\
6 \\
6\end{array}$ & $\begin{array}{l}10 \\
20 \\
40 \\
20+\text { yohimbine }\end{array}$ & $\begin{array}{l}28.8 \pm 3.0 \\
19.6 \pm 2.8^{*} \\
16.7 \pm 2.6^{*} \\
30.3 \pm 3.0\end{array}$ & $\begin{array}{l}5 \\
35 \\
45\end{array}$ \\
\hline $5 g$ & $\mathrm{CH}=\mathrm{CH}-\mathrm{C}_{3} \mathrm{H}_{7}$ & $\mathrm{CH}_{3}$ & $\begin{array}{l}5 \\
6 \\
6 \\
8\end{array}$ & $\begin{array}{l}10 \\
20 \\
40 \\
40+\text { yohimbine }\end{array}$ & $\begin{array}{l}31.6 \pm 2.6 \\
25.3 \pm 2.3 \\
19.3 \pm 2.8^{*} \\
29.1 \pm 3.1^{\S}\end{array}$ & $\begin{array}{l}0 \\
16 \\
36\end{array}$ \\
\hline $3 a$ & $\mathrm{COCH}_{3}$ & $\mathrm{C}_{2} \mathrm{H}_{5}$ & $\begin{array}{l}6 \\
6 \\
6 \\
9\end{array}$ & $\begin{array}{l}10 \\
20 \\
40 \\
20+\text { yohimbine }\end{array}$ & $\begin{array}{l}27.3 \pm 3.1 \\
17.6 \pm 2.5^{*} \\
17.9 \pm 3.1^{*} \\
28.5 \pm 2.3\end{array}$ & $\begin{array}{l}10 \\
42 \\
41\end{array}$ \\
\hline $3 \mathbf{d}^{28}$ & $\mathrm{COCH}_{3}$ & $\mathrm{CH}_{3}$ & $\begin{array}{l}6 \\
6 \\
6\end{array}$ & $\begin{array}{l}10 \\
30 \\
30+\text { yohimbine }\end{array}$ & $\begin{array}{l}24.4 \pm 3.1^{\wedge} \\
16.2 \pm 2.5^{*} \\
29.7 \pm 2.6\end{array}$ & $\begin{array}{l}19 \\
46\end{array}$ \\
\hline $3 e$ & $\mathrm{COC}_{2} \mathrm{H}_{5}$ & $\mathrm{CH}_{3}$ & $\begin{array}{l}8 \\
8 \\
8 \\
10\end{array}$ & $\begin{array}{l}10 \\
20 \\
40 \\
20+\text { yohimbine }\end{array}$ & $\begin{array}{l}27.5 \pm 3.0 \\
18.2 \pm 2.7^{*} \\
21.3 \pm 2.5^{*} \\
31.9 \pm 3.3\end{array}$ & $\begin{array}{l}9 \\
40 \\
29\end{array}$ \\
\hline $3 f$ & $\mathrm{COC}_{3} \mathrm{H}_{7}$ & $\mathrm{CH}_{3}$ & $\begin{array}{l}7 \\
7 \\
6 \\
8\end{array}$ & $\begin{array}{l}10 \\
20 \\
40 \\
20+\text { yohimbine }\end{array}$ & $\begin{array}{l}30.3 \pm 2.8 \\
22.7 \pm 3.3^{*} \\
20.5 \pm 3.1^{*} \\
28.9 \pm 2.0\end{array}$ & $\begin{array}{l}0 \\
25 \\
32\end{array}$ \\
\hline $3 g$ & $\mathrm{COC}_{4} \mathrm{H}_{9}$ & $\mathrm{CH}_{3}$ & $\begin{array}{l}6 \\
6 \\
8 \\
9\end{array}$ & $\begin{array}{l}10 \\
20 \\
40 \\
20+\text { yohimbine }\end{array}$ & $\begin{array}{l}27.9 \pm 2.5 \\
23.2 \pm 3.0^{*} \\
25.6 \pm 2.9^{*} \\
31.6 \pm 2.2\end{array}$ & $\begin{array}{l}8 \\
23 \\
15\end{array}$ \\
\hline 6 & $\mathrm{CH}_{2} \mathrm{CH}_{3}$ & $\mathrm{CH}_{3}$ & $\begin{array}{l}7 \\
6 \\
6\end{array}$ & $\begin{array}{l}10 \\
30 \\
30+\text { yohimbine }\end{array}$ & $\begin{array}{l}23.2 \pm 2.9^{*} \\
16.7 \pm 2.3^{*} \\
30.5 \pm 3.1\end{array}$ & $\begin{array}{l}23 \\
45\end{array}$ \\
\hline 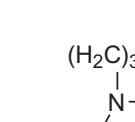 & 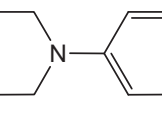 & $\mathrm{H}_{3}$ & $\begin{array}{l}6 \\
6 \\
6 \\
6\end{array}$ & $\begin{array}{l}10 \\
30 \\
40 \\
40+\text { yohimbine }\end{array}$ & $\begin{array}{l}20.2 \pm 3.3^{\wedge} \\
12.4 \pm 3.1^{*} \\
10.6 \pm 2.7^{*} \\
29.1 \pm 2.9\end{array}$ & $\begin{array}{l}33 \\
59 \\
65\end{array}$ \\
\hline
\end{tabular}

a All drugs were administrated per os $30 \mathrm{~min}$ before test.

^ $P<0.05$.

* $P<0.05$ in comparison with CMC-treated mice.

$\S$ Versus the corresponding Ai-compound.

Table 2

Antinociceptive effect of final compounds in the Writhing Test ${ }^{\mathrm{a}}$

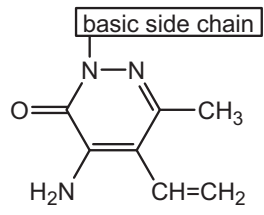

10a-c, 21a-c

\begin{tabular}{|c|c|c|c|c|c|}
\hline Compound & Basic side chain & $\mathrm{N}^{\circ}$ mice & Treatment $\left(\mathrm{mg} \mathrm{kg}^{-1}\right)$ & Abdominal constrictions & $\%$ rid $n^{\circ}$ constrictions \\
\hline CMC & & 23 & & $30.2 \pm 1.3$ & \\
\hline $10 a$ & $-\left(\mathrm{H}_{2} \mathrm{C}\right)_{3}-\mathrm{N}$ & $\begin{array}{l}6 \\
6 \\
6\end{array}$ & $\begin{array}{l}10 \\
30 \\
30+\text { yohimbine }\end{array}$ & $\begin{array}{l}30.4 \pm 2.5 \\
21.8 \pm 2.1^{*} \\
29.1 \pm 2.9\end{array}$ & $\begin{array}{l}0 \\
28\end{array}$ \\
\hline
\end{tabular}


Table 2 (continued)

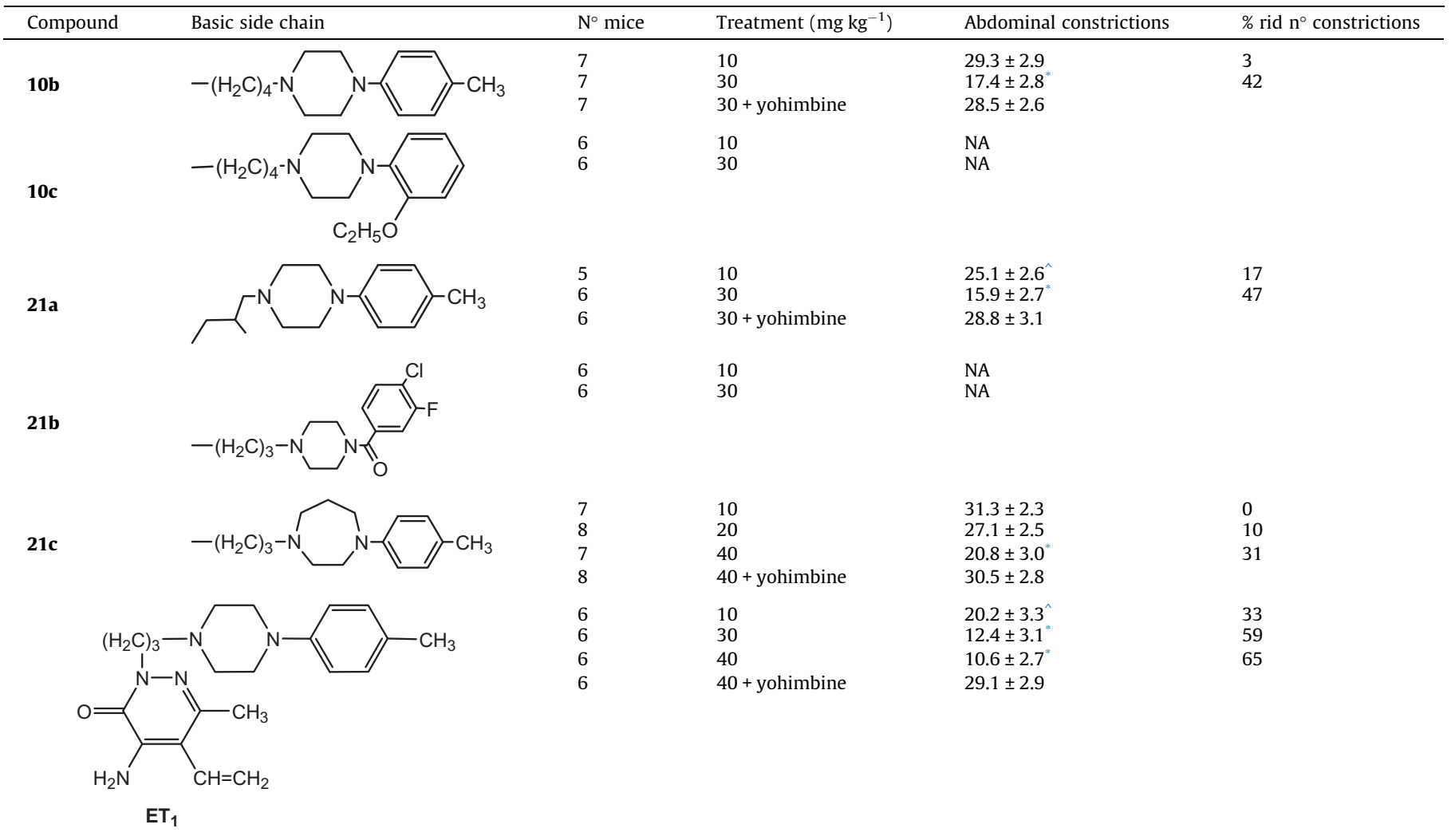

a All drugs were administrated per os 30 min before test.

$P<0.05$.

${ }^{*} P<0.05$ in comparison with CMC-treated mice.

Table 3

Antinociceptive effect of final compounds in the Writhing Test ${ }^{\mathrm{a}}$

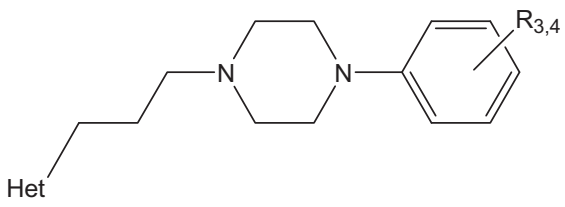

24a-e, 27a-e, 30a-c

\begin{tabular}{|c|c|c|c|c|c|c|}
\hline Compound & Het & $\mathrm{R}_{3,4}$ & $\mathrm{~N}^{\circ}$ mice & Treatment $\left(\mathrm{mg} \mathrm{kg}^{-1}\right)$ & Abdominal constrictions & $\%$ rid $n^{\circ}$ constrictions \\
\hline CMC & & & 29 & & $31.5 \pm 1.8$ & \\
\hline & & & $\begin{array}{l}7 \\
9\end{array}$ & $\begin{array}{l}10 \\
20\end{array}$ & $\begin{array}{l}28.5 \pm 2.5 \\
22.6 \pm 2.7\end{array}$ & $\begin{array}{l}9 \\
28\end{array}$ \\
\hline $24 a$ & & $4-\mathrm{F}$ & $\begin{array}{l}8 \\
10\end{array}$ & $\begin{array}{l}40 \\
40+\text { yohimbine }\end{array}$ & $\begin{array}{l}15.4 \pm 3.0^{*} \\
28.7 \pm 3.2^{\S}\end{array}$ & 51 \\
\hline $24 b$ & & $3-\mathrm{Cl}$ & $\begin{array}{l}7 \\
11 \\
8\end{array}$ & $\begin{array}{l}20 \\
40 \\
40+\text { yohimbine }\end{array}$ & $\begin{array}{l}32.5 \pm 3.0 \\
24.1 \pm 2.7^{\wedge} \\
32.6 \pm 2.9^{\S}\end{array}$ & $\begin{array}{l}0 \\
23\end{array}$ \\
\hline $24 c$ & & $3-\mathrm{OCH}_{3}$ & $\begin{array}{l}8 \\
8 \\
8 \\
8\end{array}$ & $\begin{array}{l}10 \\
20 \\
40 \\
20+\text { yohimbine }\end{array}$ & $\begin{array}{l}31.6 \pm 3.3 \\
24.9 \pm 3.2^{\wedge} \\
20.8 \pm 2.5^{*} \\
27.8 \pm 2.1^{\S}\end{array}$ & $\begin{array}{l}0 \\
21 \\
34\end{array}$ \\
\hline
\end{tabular}


Table 3 (continued)

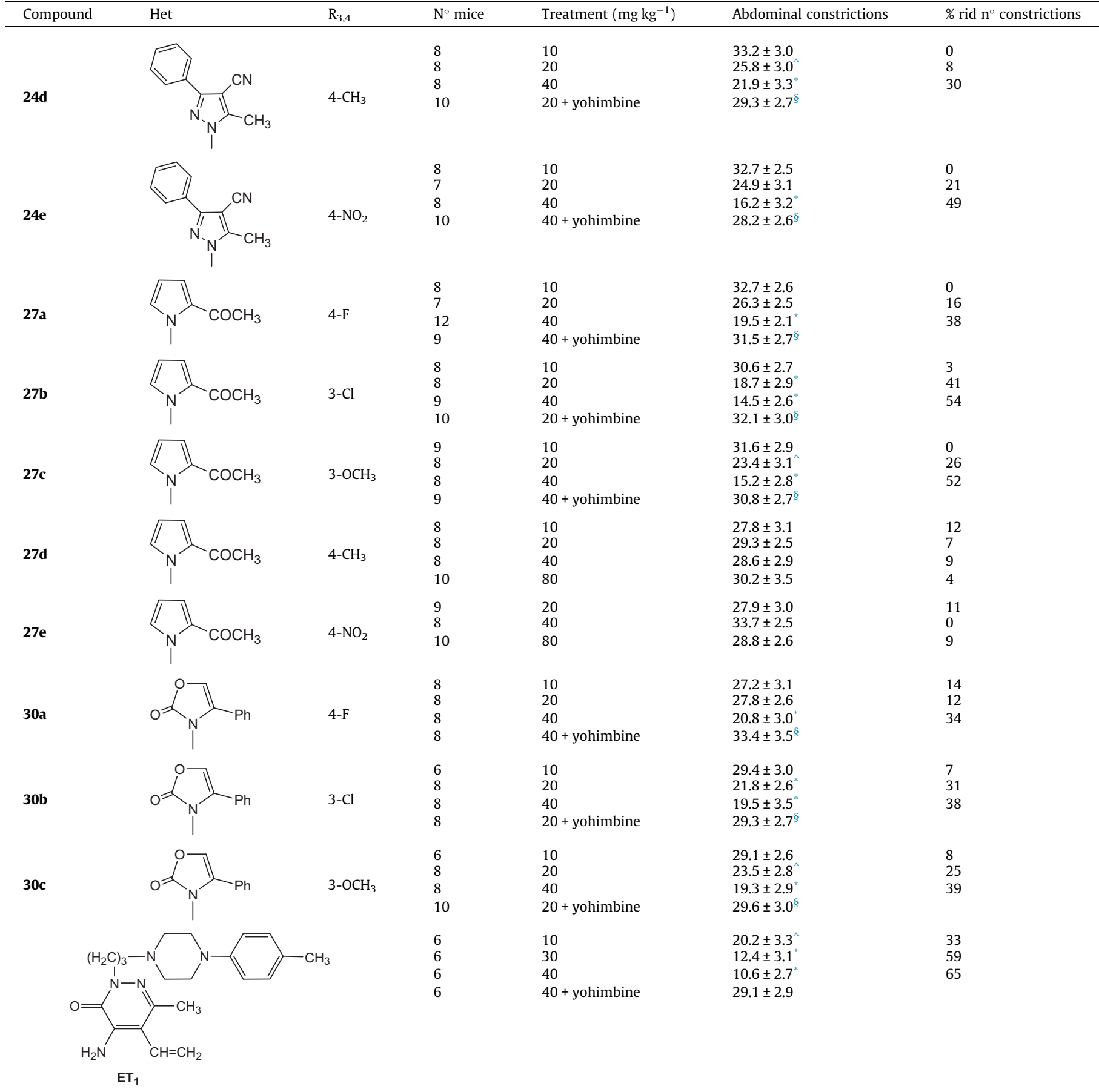

\footnotetext{
a All drugs were administrated per os 30 min before test.

^ $P<0.05$.

${ }^{*} P<0.05$ in comparison with CMC-treated mice.

$\S$ Versus the corresponding Ai-compound.
}

bearing a fluorine and a nitro group in para position of the side chain: these compounds at $40 \mathrm{mg} / \mathrm{kg}$ reduced by $51 \%$ and $49 \%$, respectively, the number of abdominal constriction and retain a weak antinociceptive activity at $20 \mathrm{mg} / \mathrm{kg}$. On the contrary, the introduction of a methyl in para position of the basic side chain (compound 24d) was associated with reduced activity (30\% of inhibition at $40 \mathrm{mg} / \mathrm{kg}$ ). In addition, compounds $24 \mathbf{b}$ and $24 \mathbf{c}$, bearing a chlorine or a methoxy group in meta position, showed a very low activity.
In the series of pyrrolo derivatives 27a-e, we observe an opposite trend of activity since the most active compounds resulted 27b and 27c (54\% and $52 \%$ of inhibition at $40 \mathrm{mg} / \mathrm{kg}$, respectively) bearing in the side chain respectively a $3-\mathrm{Cl}$ and a $3-\mathrm{OCH}_{3}$ group. As in the pyrazole series, the insertion of a methyl in para position led to the loss of activity (compound 27d) as well as compounds 27a and 27e.

Finally, the oxazolonic derivatives showed a weak antinociceptive activity (34-39\% of inhibition at $40 \mathrm{mg} / \mathrm{kg}$ ) regardless of the 
nature and position of the substituent at the phenyl ring of the side chain. These data indicate that the replacement of the pyridazinone scaffold with pentatomic heterocyclic nucleus is detrimental for activity and only few compounds induced an appreciable reduction of abdominal constriction (about $50 \%$ at $40 \mathrm{mg} / \mathrm{kg}$ ).

Finally, it's important to highlight that the antinociception of all tested compounds was completely prevented by pretreatment with the $\alpha_{2}$-antagonist yohimbine, confirming the involvement of the adrenergic system in the mechanism of action also for these new products.

\section{Conclusions}

In conclusion, we synthesized new antinociceptive agents with an appreciable activity in the Writhing Test. The most interesting terms are able to reduce the abdominal constrictions by more than $50 \%$ when administered per os at the doses of $40 \mathrm{mg} / \mathrm{kg}$ (5e, 24a, 27b and 27c). The chemical manipulation confirmed the importance of the basic side chain whose requirements seem to be different depending on the heterocyclic scaffold bearing it. As regard the heterocyclic nucleus, results demonstrated that the pyridazinone ring, widely investigated by us, could be replaced with 5-member nitrogen heterocycles, retaining a similar antinociceptive activity. For all new compounds, independently from the structure, the involvement of the adrenergic system in the mechanism of antinociception was proved, since the analgesia of tested products was completely reverted by pretreatment with $\alpha_{2}$-antagonist yohimbine.

\section{Supplementary data}

Supplementary data (synthetic routes and spectroscopic data of all new compounds synthesized and biological procedures) associated with this article can be found, in the online version, at http:// dx.doi.org/10.1016/j.bmc.2015.08.043.

\section{References and notes}

1. Levine, J. D. Neuron 1998, 20, 649.

2. Allison, M. C.; Howatson, A. G.; Torrance, C. J.; Lee, F. D.; Russel, R. I. N. Engl. J. Med. 1992, 327, 749.

3. Prasit, P.; Riendeau, D. Annu. Rep. Med. Chem. 1997, 32, 211.

4. Andersohn, F.; Suissa, S.; Garbe, E. Circulation 2006, 113, 1950.

5. Abramson, S. B.; Greenberg, J. D. Nat. Clin. Pract. Rheumatol. 2008, 4, 182.

6. Walsh, T. D. J. Pain Symptom Manage. 1990, 5, 362.

7. Russel, K.; Portenoy, M. D. J. Pain Symptom Manage. 2000, 19, S16.
8. Jensen, T. S.; Baron, R.; Haanpaam, M.; Kalso, E.; Loeser, J. D.; Rice, A. S.; Treede, R. D. Pain 2001, 152, 2204.

9. Baron, R.; Binder, A.; Wasner, G. Lancet Neurol. 2010, 9, 807.

10. Huffman, C.; Stacey, B. R.; Tuchman, M.; Burbridge, C.; Li, C.; Parson, B.; Pauer, L.; Scavone, J. M.; Behar, R.; Yurkewicz, L. Clin. J. Pain 2015. doi: 10.1097/AJP; PMID 25565583.

11. Javed, S.; Petropoulos, I. N.; Alam, U.; Malik, R. A. Ther. Adv. Chronic Dis. 2015, 6, 15.

12. Atkinson, J. H.; Slater, M. A.; Williams, R. A.; Zisook, S.; Patterson, T. L.; Grant, I.; Wahlgren, D. R.; Abramson, I.; Garfin, S. R. Pain 1998, 76, 287.

13. Arnold, L. M.; Keck, P. E., Jr.; Welge, J. A. Psychosomatics 2000, 41, 104.

14. Dworkin, R. H.; O’Connor, A. B.; Audette, J.; Baron, R.; Gourlay, G. K.; Haanpaa, M. L.; Kent, J. L.; Krane, E. J.; Lebel, A.; Levy, R. M.; Mackey, S. C.; Mayer, J.; Miaskowski, C.; Raja, S. N.; Rice, A. S. C.; Schmader, K. E.; Stacey, B. S.; Stanos, S.; Treede, R.-D.; Turk, D. C.; Walco, G. A.; Wells, C. D. Mayo Clin. Proc. 2010, 85, S3.

15. Bymaster, F. P.; Beedle, E. E.; Findlay, J.; Gallagher, P. T.; Krushinskj, J. H.; Mitchell, S.; Robertson, D. W.; Thompson, D. C.; Wallace, L.; Wong, D. T. Bioorg. Med. Chem. Lett. 2003, 63, 308.

16. Lecrubier, Y. Hum. Psychopharmacol. Clin. Exp. 1997, 12, S127.

17. Butera, J. A. J. Med. Chem. 2007, 50, 2543.

18. Gilron, I.; Dickenson, A. H. Exp. Opin. Emerg. Drugs 2014, 19, 329.

19. Dal Piaz, V.; Giovannoni, M. P.; Ciciani, G.; Barlocco, D.; Giardina, G.; Petrone, G.; Clarke, G. D. Eur. J. Med. Chem. 1996, 31, 65.

20. Pieretti, S.; Dal Piaz, V.; Matucci, R.; Giovannoni, M. P.; Galli, A. Life Sci. 1999, 65, 1381.

21. Dal Piaz, V.; Pieretti, S.; Vergelli, C.; Castellana, M. C.; Giovannoni, M. P. J. Heterocycl. Chem. 2002, 39, 523 .

22. Dal Piaz, V.; Vergelli, C.; Giovannoni, M. P.; Scheideler, M. A.; Petrone, G.; Zaratin, P. Farmaco 2003, 58, 1063.

23. Giovannoni, M. P.; Vergelli, C.; Ghelardini, C.; Galeotti, N.; Bartolini, A.; Dal Piaz, V. J. Med. Chem. 2003, 46, 1055.

24. Cesari, N.; Biancalani, C.; Vergelli, C.; Dal Piaz, V.; Graziano, A.; Biagini, P.; Ghelardini, C.; Galeotti, N.; Giovannoni, M. P. J. Med. Chem. 2006, 49, 7826.

25. Giovannoni, M. P.; Cesari, N.; Vergelli, C.; Graziano, A.; Biancalani, C.; Biagini, P.; Ghelardini, C.; Vivoli, E.; Dal Piaz, V. J. Med. Chem. 2007, 50, 3945.

26. Vergelli, C.; Giovannoni, M. P.; Pieretti, S.; Di Giannuario, A.; Dal Piaz, V.; Biagini, P.; Biancalani, C.; Graziano, A.; Cesari, N. Bioorg. Med. Chem. 2007, 15, 5563.

27. Giovannoni, M. P.; Ghelardini, C.; Vergelli, C.; DalPiaz, V. Med. Res. Rev. 2009, $29,339$.

28. Biancalani, C.; Giovannoni, M. P.; Pieretti, S.; Cesari, N.; Graziano, A.; Vergelli, C.; Cilibrizzi, A.; Di Gianuario, A.; Colucci, M.; Mangano, G.; Garrone, B.; Polenzani, L.; Dal Piaz, V. Pain 2009, 52, 7397.

29. Sprio, V.; Ajello, E.; Mazza, A. Anal. Chim. 1967, 57, 836.

30. Giovannoni, M. P.; Vergelli, C.; Biancalani, C.; Cesari, N.; Graziano, A.; Biagini, P.; Gracia, J.; Gavaldà, A.; Dal Piaz, V. J. Med. Chem. 2006, 49, 5363.

31. Giovannoni, M. P.; Ciciani, G.; Cilibrizzi, A.; Crocetti, L.; Daniele, S.; Di Cesare Mannelli, L.; Ghelardini, C.; Giacomelli, C.; Guerrini, G.; Martini, C.; Trincavelli, M. L.; Vergelli, C. Eur. J. Med. Chem. 2015, 89, 32.

32. Renzi, G.; Dal Piaz, V. I. Gazz. Chim. Ital. 1965, 95, 1478.

33. Saito, K.; Nakao, A.; Shinozuka, T.; Shimada, K.; Matsui, S.; Oizumi, K.; Yano, K.; Ohata, K.; Nakai, D.; Nagai, Y.; Naito, S. Bioorg. Med. Chem. 2013, 21, 1628.

34. Dal Piaz, V.; Ciciani, G.; Chimici, S. Heterocycles 1985, 23, 365.

35. Bottari, F.; Nannipieri, E.; Saettone, M. F.; Serafini, M. F. J. Med. Chem. 1972, 15, 39.

36. Koster, R.; Anderson, M.; De Beer, E. J. Fed. Proc. 1959, 18, 412. 